\title{
Instituições e política comercial nos Estados Unidos: política internacional, demandas domésticas e design institucional *
}

\author{
Filipe de Almeida do Prado Mendonça ${ }^{* *}$ \\ Thiago Lima \\ Tullo Vigevani ${ }^{* * * *}$
}

\begin{abstract}
Resumo
O artigo aborda a institucionalização da política comercial dos Estados Unidos a partir de uma perspectiva histórica, dando ênfase especial aos desenvolvimentos que ocorreram a partir de meados da década de 40 até os anos 80 . Para realizarmos esta tarefa, construímos uma narrativa que leva em conta os desenvolvimentos do sistema internacional e da política doméstica norte-americana. Buscamos entender como essas duas estruturas levaram a mudanças no processo de formulação de política comercial, bem como a influência dessas mudanças na política comercial em si, que se tornou menos internacionalista e mais focada na noção de fair trade.
\end{abstract}

Palavras-chave: Estados Unidos - Política Comercial, História; Relações econômicas internacionais; Comércio Internacional - História.

\section{Abstract \\ Institutions and trade policy in the United States: international politics, domestic demands and institutional design}

The article addresses the institutionalization of the United State's trade policy from a historical perspective, with particular emphasis on developments that have occurred since the mid-40s until the 1980s. To accomplish this task, we build a narrative that takes into account developments in the international system and American domestic politics. We seek to understand how these two structures have led to changes in the trade policy formulation process as well as the influence of these changes on trade policy itself, which became less internationalist and more focused on the notion of fair trade.

Keywords: United States - Trade policy, History; International relations; International political economy; International Trade and Finance.

JEL F13, F59, N72, F42, B27.

\section{Introdução}

A centralidade dos EUA nas relações comerciais internacionais é inquestionável. Por ser a maior economia do mundo - mas também pelo seu elevado

* Artigo recebido em 5 de abril de 2014 e aprovado em 18 de fevereiro de 2017.

** Professor da Universidade Federal de Uberlândia ( $\underline{\mathrm{UFU}}$ ) / Pesquisador do Instituto Nacional de Ciência e Tecnologia para Estudos sobre os Estados Unidos (INCT-INEU), Uberlândia, MG, Brasil. E-mail: mendonca@ufu.br.

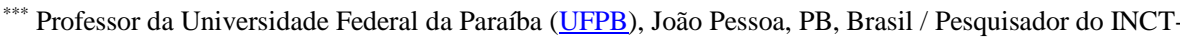
INEU. E-mail: tlima@ccsa.ufpb.br.

***** Professor da Universidade Estadual Paulista (Unesp), Marília, SP, Brasil / Pesquisador do INCT-INEU. E-mail: vigevanit@uol.com.br. 
peso político e militar - sua incidência na ordem internacional é decisiva para os negócios e para as possibilidades de desenvolvimento dos países. Portanto, examinar a formulação da política comercial nos EUA contribui não só para uma melhor compreensão das ações daquele país, mas também das próprias relações econômicas internacionais.

O fio condutor desta análise é composto por instituições relacionadas à formulação de política comercial. Não é demais lembrar que as instituições são elementos-chave dos processos políticos. Por um lado, representam uma constelação de forças que conseguiu cristalização mais ou menos forte por meio do Estado. Isto é, espelham, com maior ou menor nitidez, uma relação de poder. Por outro lado, e em decorrência do que foi dito, as instituições direcionam ações e limitam o leque de alternativas disponíveis aos atores que visam avançar seus interesses por meio do Estado.

Por isso, com o fito de compreender a política comercial dos EUA, o artigo aborda a institucionalização daquela política ao longo do tempo. Partindo do pressuposto de que determinadas políticas públicas sofrem influência dos âmbitos doméstico e internacional, buscamos entender as forças políticas dessas duas esferas que levaram a mudanças nas instituições de formulação de política comercial. Como método, recorremos à revisão bibliográfica e à análise documental e de legislação, a partir de uma perspectiva histórica, dando ênfase aos desenvolvimentos que ocorreram de meados da década de 40 até os anos 80. Da análise, sintetizamos as características e processos de mudança institucionais mais marcantes dos períodos históricos, permitindo colocar em perspectiva os diferentes arranjos.

O marco temporal corresponde a três períodos bem sedimentados na literatura: do pós II Guerra até meados da década de 1960; da década de 1970 até meados de 1980; e de 1979 até 1988. Cada período corresponde a uma seção do artigo. O primeiro período é caracterizado por um posicionamento internacionalista que aceitava, na visão doméstica, algumas desvantagens econômicas em troca de benefícios no cenário político internacional. Assim, a manutenção da Aliança Atlântica e a aliança com o Japão tornaram a política comercial secundária no conjunto maior da política externa, por causa da ênfase inicial da Guerra Fria em questões militares e estratégicas. No cenário doméstico o posicionamento internacionalista foi viabilizado pela bonança econômica que permitia arcar com os custos advindos da liderança no plano internacional, e por um arranjo políticoinstitucional que esquivava o Congresso, em alguma medida, de demandas protecionistas.

O segundo período é caracterizado por um forte questionamento interno da posição internacionalista. Com o arrefecimento da Guerra Fria e a ascensão de novos polos industriais, principalmente o alemão e o japonês, intensas pressões 
protecionistas tiveram impacto direto no Congresso. Por um lado, deixava de fazer sentido relegar a política comercial para um segundo plano. Por outro, a perda de competitividade incitava as demandas de grupos protecionistas, contribuindo para significativas alterações no design institucional de política comercial, as quais possibilitaram um maior acesso de grupos particularistas ao seu processo de formulação.

O terceiro período é caracterizado por uma nova concepção de política comercial, no qual se tornam correntes medidas unilaterais por parte dos Estados Unidos contra os seus principais competidores econômicos. Exemplo marcante desse período é a utilização da Seção 301 da lei comercial, pela qual o United States Trade Representative (USTR) exigia a abertura de setores econômicos de parceiros comerciais sob a pena impor restrições de acesso ao mercado dos EUA. Brasil, Comunidade Europeia, Coreia do Sul, Índia, Japão e Taiwan foram alvos dessas medidas. Tal investidura acabou por minar a resistência de muitos países a negociarem a Rodada Uruguai do GATT. Essa postura mais agressiva foi, contudo, exercida em meio a uma tensão entre o desejo de acesso de grupos protecionistas ao processo de formulação de política comercial e os obstáculos impostos pelo Executivo, mais pró-livre-comércio ${ }^{1}$.

\section{Internacionalismo: Guerra Fria e blindagem doméstica}

Desde sua fundação até meados da década de 1930 os Estados Unidos mantiveram uma política comercial predominantemente protecionista. Tal política pode ser atribuída à capacidade de articulação de grupos de pressão junto aos congressistas e também ao interesse de Estado $^{2}$. No primeiro caso, o sistema políticoeleitoral norte-americano incentivava um comportamento paroquialista (Schattschneider, 1935). O segundo caso tem a ver com o objetivo de criar condições

(1) São pelo menos quatro as justificativas para se desenvolver um estudo sobre a formulação da política comercial norte-americana no Brasil: 1) A centralidade dos EUA no comércio internacional, reacendida recentemente pela conclusão Parceria Transpacífico, acordo preferencial de comércio que envolve 10 países, incluindo o Japão; 2) Alterações nas instituições de política comercial podem ter impactos significativos tanto para os atores que visam o mercado norte-americano, quanto para aqueles que disputam mercados de terceiros com os estadunidenses; 3) Fazer uma leitura do ponto de vista brasileiro contribui com lições que podem, com o devido cuidado na sua transposição, servir de exemplo para o nosso país; 4) O exame histórico da referida política pode servir de subsídio para a formação de novas gerações de especialistas que realizam negociações com os EUA.

(2) Ao perceber a importância do tema, Hamilton (1993), em 1787, discute seu significado, relacionandoo com a importância da criação de um grande Estado nacional. Seu artigo "A utilidade da União no tocante ao comércio e à marinha" mostra como o comércio internacional pode tornar-se instrumento de poder, na busca do espaço mundial que naquela fase apenas os europeus detinham. Adicionalmente, Hamilton e outros Federalistas acreditavam que, para evitar a tirania contra minorias, era importante estimular o comércio e a manufatura garantindo assim a existência de diversos grupos de interesse na república (vide Plattner, 1994). Sobre o protecionismo norteamericano ver, entre outros, Chang, Ha-Joon. Chutando a escada: a estratégia do desenvolvimento em perspectiva histórica. São Paulo: Unesp, 2004 e Reinert, Erik S. How rich countries got rich and why poor countries stay poor. New York: Public Affairs, 2009. 
para a industrialização. A partir de meados da década de 1930 o discurso do livrecomércio e uma política de liberalização comercial foram adotados para o setor industrial. Algumas razões históricas, como o nacionalismo econômico que contribuiu para a eclosão da I Guerra Mundial e a Grande Depressão, consolidaram a opção pela liberalização manufatureira no Executivo e em outros atores relevantes. Tal opção, é preciso destacar, veio quando o poder político e estratégico, a economia e a moeda, tornaram a política liberalizante um caminho necessário para o contínuo crescimento do poder norte-americano (Frieden, 2008).

Após o término da II Guerra e com o surgimento da Guerra Fria, havia consenso político nos Estados Unidos de que eles deveriam garantir o estabelecimento das bases da ordem capitalista internacional. Dever-se-ia apoiar, entre outras medidas, negociações comerciais liberalizantes, principalmente em manufaturas, e garantir a estabilidade do sistema. Essa postura internacionalista, que identifica os interesses nacionais com um ambiente internacional pacífico, ganha contornos mais claros nos esforços de manutenção da Aliança Atlântica e na aliança com o Japão. Paralelamente, mas de forma menos engajada, buscava-se atrair ao bloco capitalista os novos países que surgiam no Terceiro Mundo. Em outras palavras, de 1945 até meados dos anos 60, os Estados Unidos realizavam concessões econômicas assimétricas ${ }^{3}$ aos seus principais aliados visando a estabilidade do sistema - desejável também para o investimento direto norte-americano no exterior - e para afastá-los da esfera de influência soviética ${ }^{4}$ (Zeiler, 1991; Gilpin, 2002; Frieden, 2008).

No plano doméstico, acreditava-se que a lei protecionista Smoot-Hawley, de 1930, fora um dos fatores que contribuíram para as guerras comerciais da década de 1930. Para evitar a repetição desses acontecimentos, era preciso reverter o isolacionismo da política externa em relação à Europa. As lições que foram tiradas da lei de 1930 influenciaram na modelagem do conjunto das propostas para o comércio internacional. Assim, os Estados Unidos passaram a liderar a construção de um regime de comércio liberal para manufaturas, o General Agreement on Tariffs and Trade (GATT). Esse projeto foi viabilizado, no plano doméstico, por um arranjo institucional que blindava o Congresso de pressões protecionistas do setor industrial, bem como pela exclusão da agricultura das intenções de liberalização (Goldstein, 1993; O’Shea, 1993; Oliveira, 2011).

(3) É preciso enfatizar que com a agricultura foi diferente, pois os EUA moldaram o regime do GATT de modo a excetuá-la dos compromissos de liberalização e de regulamento de subsídios (Oliveira, 2011; Lima, 2014).

(4) Esse parágrafo remete à discussão sobre a Teoria da Estabilidade Hegemônica, contestada por uns e endossada por outros (Gilpin, 1981; Keohane, 1988). Aceitamos a teoria como útil para explicar o período em tela. Além disso, ela possui uma importância endógena, na medida em que os atores domésticos relevantes dão credibilidade a seus argumentos, refutando ou aderindo a eles (Anderson, 1960; Gardner, 1960; Aubrey, 1961). 


\subsection{Sistema de formulação de política comercial nos EUA}

O arranjo institucional de política comercial, no imediato pós II Guerra, favorecia o projeto de liberalização de manufaturas. Ele criava contrapesos ao que restava de pressões protecionistas, mantendo diretrizes liberalizantes mesmo com mudanças nas preferências internas (Destler, 1995; Eckes, 1999, Mundo, 1999). Entre os obstáculos às pressões protecionistas estavam: mecanismos de defesa, ajuste e proteção comerciais geridos pela burocracia em processos quasi-judiciais, como a escape clause, o antidumping e o Countervailing Duties (CVD); e órgãos burocráticos, como veio a ser o Office of the Special Trade Representative, posteriormente renomeado United States Trade Representative (USTR) ${ }^{5}$. Os contrapesos também podem ser entendidos como uma blindagem que protegia os congressistas das demandas protecionistas ${ }^{6}$. Para não perderem os votos nem os recursos dos setores protecionistas para campanhas eleitorais, os congressistas trabalhavam sobre os mecanismos de defesa e alívio comerciais, mantendo diretrizes liberalizantes e evitando o protecionismo (Destler, 1995). O sistema contava ainda com um mecanismo instituído no Reciprocal Trade Agreements Act de 1934, que delegava autoridade do Congresso ao Executivo. Pela Constituição, cabe ao Congresso regular o comércio exterior e ao Presidente negociá-lo. Quando recebia a autorização, o Executivo ganhava sinal verde para negociar, mas o Congresso mantinha papel importante ao determinar limites à ação. Em conjunto, o arranjo institucional tinha o efeito de minar grupos protecionistas localizados, desestimulando o paroquialismo em favor de uma política nacional liberalizante em manufaturas (Destler, 1995; Eckes, 1999).

O arranjo institucional possibilitou a continuidade da estratégia de liberalização mesmo quando as condições econômicas domésticas que viabilizavam politicamente o livre-comércio começaram a se deteriorar com o aumento da competitividade estrangeira, principalmente a partir de 1955 em diante. As principais dificuldades que se colocaram neste período foram a diminuição da participação dos Estados Unidos nas exportações mundiais e o déficit no balanço de pagamentos que, de 1949 a 1959, possuía várias causas, entre elas: compromissos relativos à reconstrução e proteção militar do Ocidente; grande fluxo de investimento privado norte-americano ao exterior; aumento de importações em função do crescimento econômico; e aumento da competitividade de europeus e japoneses. Para Anderson (1960), então secretário do Tesouro de Eisenhower, o início de um aparente declínio econômico norte-americano, que se agravava em função do déficit de 1959, não seria solucionado por meio de medidas unilaterais, como barreiras a importações, restrição

(5) Optamos por manter certos nomes e siglas em inglês por serem a forma que mais comumente aparecem na literatura e no jargão comercial.

(6) A isso se soma a luta contra o comunismo, que impulsionava uma maior atuação internacional para coibir as ações e ideologias pró-socialistas. 
ao fluxo de capital privado, interrupção nos programas de ajuda, nos empréstimos públicos e nas operações militares. Ao contrário, o governo deveria "enfatizar a expansão do comércio mundial sobre bases multilaterais e com um ataque contínuo às barreiras ao comércio" (Anderson, 1960, p. 428. Tradução nossa).

Os mecanismos de defesa e alívio comerciais eram importantes pilares daquele arranjo institucional. A forma de aplicação desses mecanismos, também conhecidos como remédios administrativos ou comerciais, variou ao longo do tempo. Mais especificamente, os procedimentos para a elegibilidade e certificação aos remédios administrativos foram modificados com o propósito de facilitar ou dificultar a concessão de alívio ou proteção à medida que a deterioração econômica dos Estados Unidos se acentuava (Mundo, 1999). Aliás, modificações nos mecanismos de defesa comercial são respostas institucionais tradicionais às demandas protecionistas na história da política comercial dos EUA até hoje (Mendonça; Lima, 2013). Além dos convencionais antidumping ${ }^{7}$ e coutervailing duties $^{8}$, escape clause $^{9}$ e Trade Adjustment Assistance ${ }^{10}$, outros remédios administrativos foram criados no pós-II Guerra, buscando servir como proteção e ajuste à competição estrangeira em setores domésticos e como válvulas de escape às pressões protecionistas no Congresso. Ao criar novos remédios administrativos ou modificar esses mecanismos, os congressistas canalizavam as demandas protecionistas à administração, ao mesmo tempo em que argumentavam estar agindo no interesse do seu eleitorado. A utilização destes remédios reflete, em comparação com o pós-1974, ideias e condições políticas e econômicas domésticas que restringiam o protecionismo como resposta a possíveis "deslealdades comerciais" (Goldstein, 1993). Assim, as demandas protecionistas, que poderiam tanto minar a própria abertura comercial quanto causar constrangimentos à posição de líder do GATT, eram defletidas pelo arranjo institucional ${ }^{11}$.

(7) Este remédio administrativo surgiu em 1914, no Federal Trade Comission Act, tornando ilegais práticas de concorrência comercial desleais por entes norte-americanos. Em 1921 foi aprovada a primeira legislação antidumping visando impedir as práticas desleais internacionais, impondo tarifas aos produtos comercializados a preços desleais.

(8) Este remédio administrativo surgiu na legislação em 1909 para aplicar uma segunda escala de tarifas em países com práticas desleais, principalmente subsídios fornecidos por governos estrangeiros às suas empresas.

(9) A "escape clause" é uma cláusula de exceção, original da lei norte-americana, que possibilita abrigo para empresas afetadas por importações sob o argumento de ressalva, por meio de suspensão de concessões ou maiores tarifas. Esta cláusula foi incorporada pelo GATT, no artigo XIX.

(10) Este remédio foi criado pelo Trade Expansion Act (1962) e tinha como objetivo fornecer ajuda financeira e/ou técnica a trabalhadores e empresas que sofrem com competição estrangeira, para que se adaptem e se tornem competitivos (Mundo, 1999).

(11) Mas não completamente. Apesar de o termo "livre comércio" ser corrente no discurso norte-americano, é mais adequado caracterizar a política como uma de liberalização. A proteção e o amparo aos prejudicados eram entendidos como necessários. No plano doméstico, os remédios administrativos refletem esse entendimento, enquanto no plano internacional existe um certo liberalismo amortecido, o embedded liberalism (Ruggie, 1982). Adicionalmente, não se pode esquecer que o setor agrícola foi deliberadamente excluído de maiores esforços de liberalização. 
É importante destacar, no entanto, que o GATT foi o resquício da Organização Internacional do Comércio (OIC) (Cruz, 2005; Barton et al., 2006). A Carta da instituição foi assinada em março de 1948, por 53 países, ao final de uma Conferência das Nações Unidas em Havana. Os negociadores dos EUA participaram ativamente da concepção e do tratado que comporia a nova Organização, mas o texto sequer foi submetido a uma votação formal no Congresso devido à aversão explícita do legislativo ao projeto. Por um lado, o GATT foi um reflexo do protecionismo comercial dos EUA, sobretudo na área agrícola. Por outro, a recusa do país em aceitar a normatização internacional de políticas econômicas e sociais mais abrangentes e relacionadas ao comércio, como regras relativas ao pleno emprego e à promoção do desenvolvimento, por exemplo, demonstrava os limites internos ao projeto de reconstrução da ordem econômica internacional. Como buscaremos demonstrar, os arranjos institucionais são maneiras de tentar superar, em alguma medida, esses limites internos.

\subsection{Insatisfação, o Trade Expansion Act e o Special Trade Representative}

A insatisfação de parte dos trabalhadores, empresas e agricultores com relação à condução da política comercial do país ganhou força no início da década de 1960 e concentrou-se em três pontos: aumento da concorrência estrangeira no mercado doméstico; barreiras não-tarifárias e práticas dos concorrentes consideradas desleais; e o modo como as negociações internacionais eram conduzidas (Dryden, 1995; Destler, 1995). Diante desse cenário, o setor privado acreditava que as negociações comerciais, tal como conduzidas pelo Departamento de Estado em conjunto com o de Comércio, nas primeiras Rodadas do GATT, principalmente na Rodada Dillon (1960-61), foram amplamente desfavoráveis para os interesses comerciais dos Estados Unidos. A acusação era que o Departamento de Estado estaria utilizando a política comercial como instrumento da política externa, causando danos a certos segmentos econômicos para obter ganhos diplomáticos.

Nesse contexto, o setor privado passou a pressionar a administração Kennedy por medidas protecionistas e por respostas à concorrência de europeus e japoneses, considerada desleal. Muitos grupos de interesses também se mobilizaram para fazer lobby junto ao poder legislativo, pois este poder era visto como mais sensível às demandas protecionistas e à ideia de diminuir o poder do Departamento de Estado sobre a política comercial. Com o decorrer do período presidencial, Kennedy absorveu a ideia da necessidade de satisfazer, em alguma medida, os interesses de cadeias produtivas e grupos empresariais ligados ao comércio internacional que se viram prejudicados pelos acordos alcançados. Paralelamente, o Legislativo norte-americano tornou-se palco de intensas discussões sobre a questão. Congressistas Democratas e parte dos Republicanos, sobretudo dos estados do cinturão agrícola, pressionavam Kennedy por medidas protecionistas e pelo 
endurecimento nas negociações internacionais. Há, neste momento, uma certa erosão da rigidez partidária quanto à política comercial. Antes Republicanos eram mais protecionistas e Democratas, mais liberais. Contudo, com a mudança nas condições econômicas de parte de seus respectivos eleitorados, Democratas e Republicanos passaram a atuar conforme uma lógica diferente da tradicional de seus partidos, não sendo mais tão rígidos os respectivos rótulos (Goldstein, 1993; Destler, 1995; Hiscox, 1999). Mundo (1999) afirma que não chegou a ocorrer uma completa inversão de polos, mas sim a decadência de um partido como portador de uma ideia de comércio. A análise de Baldwin (1984) é parecida com a de Mundo (1999), porém, atribui maior importância à posição partidária no debate comercial do início década de 1960, algo que se esvairia na década seguinte ${ }^{12}$.

Em meio ao debate, a administração Kennedy buscou a aprovação do Congresso de uma nova lei comercial, o Trade Expansion Act de 1962. O objetivo fundamental era obter a delegação de autoridade para negociar uma Rodada do GATT abrangente e com capacidade de cooptar os novos países do sistema internacional recém-descolonizados. Esta discussão tinha como um dos primeiros tópicos de sua agenda o estabelecimento de checks and balances no processo de formulação e implementação da política de comércio, levando-se em consideração os diferentes atores intervenientes. $\mathrm{O}$ objetivo era encontrar o design institucional adequado para que o país defendesse seus interesses de Estado, compatibilizandoos, ao máximo possível, com os interesses setoriais. O Congresso vinha há algum tempo buscando limitar o poder do presidente sobre o comércio internacional, mas o Executivo solicitava que o exercício do mandato negociador deveria ser do próprio presidente. Como solução para o impasse, Willbur Mills, chairman do Comitê de Ways and Means da Câmara de Representantes, o mais importante comitê de comércio da casa, propôs emenda para solucionar a questão da condução da política comercial (Dryden, 1995; Destler, 1995; Eckes, 1999). Mills propôs a criação de órgão para representar o presidente nas negociações internacionais, de modo a retirar esse papel do Departamento de Estado, o que foi reconhecido como necessário. $\mathrm{O}$ projeto fora aprovado pelo Congresso, criando o Office of the Special Trade Representative (STR). O Representante Estadunidense para o Comércio, alocado no Escritório Executivo da Presidência, estava autorizado a negociar todos os acordos comerciais relativos ao Trade Expansion Act of 1962. Esta instituição tinha como intuito ser mais permeável aos interesses privados do que o Departamento de Estado, aumentando a eficácia da política de comércio exterior, do ponto de vista dos

12 A posição de Republicanos e Democratas não pode ser corretamente apreendida apenas pelas votações nominais. De certo, são fatos de muita relevância, mas as votações são resultados de barganhas anteriores que podem resultar nos votos finais, o que nos faz valorizar as interpretações de Goldstein (1993) e Destler (1995), que realizaram exames mais históricos, pautados em análises documentais e de discurso. Para uma discussão sobre limites das votações nominais para aferir a posição de Democratas e Republicanos, ver (Hiscox, 1999). 
empresários e sindicatos, e absorvendo interesses de atores menos poderosos, sem comprometer os interesses políticos e estratégicos norte-americanos (Zeiler, 1991).

Por meio de Executive Order, o STR era mais uma saída institucional que se somava ao arranjo existente de modo a manter o país atuando pela liberalização comercial internacional. A agência deveria ser um negociador do Executivo que se reportava e dialogava com o Congresso. Na prática, a agência teve pouca autonomia na Rodada Kennedy e em outras negociações do período. O Departamento de Estado e o Conselho de Segurança Nacional (CSN) continuavam a ser os principais formuladores, cabendo ao STR apenas a execução das ordens dadas pelo Executivo. Como veremos, a agência se fortalece na década seguinte, ganha poder sobre mecanismos de defesa e alívio comerciais contra o comércio desleal e também sobre a formulação de política comercial, de modo a favorecer o desenvolvimento de sua estratégia de política comercial. Esse fortalecimento, porém, nunca ocorreu de forma inconteste e veio a ser bastante reduzido no início dos anos 1980.

\section{Incerteza e Transição: novos arranjos institucionais e nova postura internacional}

O início da década de 1970 é marcado por sinais intensos do declínio econômico dos Estados Unidos (Keohane, 1988; Kennedy, 1989). As divergências em relação à política internacional, ao desempenho econômico e ao sistema político interno são marcas importantes do período. Baseado no que acontecia nestas três esferas, argumentava-se que eram necessárias reformas institucionais para identificar os interesses norte-americanos em um contexto de perda relativa de poder.

No campo político-estratégico, este período foi embalado pela coexistência pacífica e pela détente. Não havia mais a iminência de confrontação direta entre os Estados Unidos e a União Soviética. Isso fez com que diminuísse o estímulo às concessões unilaterais liberalizantes por parte dos Estados Unidos nas negociações internacionais. A Europa Ocidental e o Japão passavam a serem vistos não apenas como aliados incondicionais, mas também como vorazes concorrentes comerciais, já que nos anos 1970 estavam consolidados como grandes potências econômicas. O tema da segurança não ocupava mais o topo absoluto da agenda internacional dos Estados Unidos, cedendo espaço para temas econômicos, ficando mais difícil argumentar que resultados insatisfatórios nas negociações comerciais do ponto de vista do setor privado eram, na verdade, estratégicos para o Estado. Assim, a política de comércio internacional ganhou uma lógica mais autônoma, dissociada da política de segurança (Dryden, 1995; Destler, 1995).

No campo das políticas econômicas, entre meados da década de 1960 e o início dos anos 1970, percebia-se que o ciclo virtuoso do modelo de desenvolvimento do pós-45 atingia certo limite. Em termos de poder econômico, afirmava-se na época 
que a participação do PIB norte-americano no mundial caíra de 40,1\% em 1965 para 29,2\% em 1981 (Maddison, 2003). Esses dados, embora contestáveis, são importantes uma vez que influenciavam a percepção dos atores.

De fato, a crise afetou fortemente os Estados Unidos. O dólar já não inspirava a confiança de antes e o déficit comercial norte-americano havia crescido consideravelmente ${ }^{13}$. Além disso, a ascensão econômica da Alemanha e do Japão, posteriormente dos $\mathrm{NIC}^{14}$, tornou o setor privado norte-americano mais sensível à competição externa, nos EUA e nos mercados estrangeiros. Não havia mais uma ordem econômica e financeira como no início do sistema de Bretton Woods. Domesticamente, era crescente a percepção de que "Unfortunately, it would appear that we [the United States] cannot figure out what today's rules really are. We are drowing in a kind of national confusion, floundering in our attempts to find a way out, all the while wondering why the old formula no longer pays off" (Newman, 1990, p. 355).

Esta incerteza proporcionada pelo sistema econômico internacional, que não se limitou aos Estados Unidos, intensificou o debate doméstico norte-americano, aumentando as preocupações de vários setores, que passavam a demandar maior proteção. Criou-se um ciclo no qual questões domésticas e internacionais se entrelaçavam com maior vigor na agenda comercial.

Diferentemente do período anterior, entre 1965 e 1988, o aprofundamento das dificuldades econômicas, com destaque para um saldo comercial em tendência negativa, bem como as novas dinâmicas do sistema financeiro internacional, intensificaram as ideias de que o internacionalismo não era mais viável nem desejável aos Estados Unidos. Era preciso agir para recuperar o bom desempenho econômico e manter supremacia econômica que estava sendo ameaçada principalmente pelos japoneses. Aliás, foi essa a conclusão de um relatório denominado "United States International Economic Policy in an Interdependent World”, publicado em julho de 1971 pela Commission on International Trade and

(13) Devido aos limites de espaço optamos por deixar de lado partes importantíssimas do contexto financeiro e monetário e que marcaram significativamente o período. Referimo-nos, sucintamente, aos eventos que levaram à quebra do sistema de Bretton Woods. Entre esses eventos, é de importância capital o desequilíbrio fiscal experimentado pelos EUA, em grande parte decorrentes dos compromissos externos, como a Guerra do Vietnã, e de políticas internas, como o projeto Grande Sociedade do presidente Johnson. Outro ponto de suma importância era a política monetária expansiva, que causava inflação e financiava a política externa dos EUA, mas ao mesmo tempo enfraquecia a moeda americana como âncora do padrão dólar-ouro no qual se fundava o sistema de Bretton Woods. Esses elementos foram amplamente discutidos nas obras de Block (1980); Helleiner (1994); Eichengreen (2000); entre outros. Agradecemos ao parecerista por enfatizar esse ponto.

(14) NIC foi o nome dado a um conjunto de países que, em meados dos anos 1960, passaram a modificar sua estrutura econômica da direção da industrialização, distanciando-se das economias periféricas fundamentalmente primárias. Eram, por exemplo, Brasil, México, Coreia do Sul e Taiwan. Para uma discussão a respeito, ver Evans, Peter. Embedded autonomy: states and industrial transformation. Princeton: Princeton University Press, 1995. 
Investment Policy (mais conhecida como Williams Commission), que era liderada por Albert L. Williams da IBM, e formada por líderes empresariais, sindicais, acadêmicos e burocracias.

A Comissão apontava a falta de disposição de outros países em cooperarem para a redução do déficit dos Estados Unidos. Trazia ainda um programa para aumentar a integração da economia norte-americana à mundial, de modo a fortalecer a economia doméstica. "Included in this program were suggestions on how to strengthen the domestic economy, but the gist of the program was a call for international negotiations to deal with problems of international payments and trade" (Winham, 1986, p. 74). Os aumentos do fluxo e da importância do comércio intra-indústria para as empresas norte-americanas eram as principais razões para a defesa da abertura comercial dos mercados internacionais. A proposta de negociações multilaterais era detalhada e incluía a ideia de criação de códigos para disciplinar as legislações nacionais de maneira a não restringir o comércio: "Without such an effort, the commission foresaw that additional distortions would probably arise in international trade as governments sought to intervene to protect their constituents in an increasingly unFair Trade system" (Winham, 1986, p. 75).

Os textos que compõem o relatório são de grande valor para entender o período. Por isso é importante dar-lhes uma maior atenção. Além da proposta de uma nova Rodada do GATT, principalmente para lidar com barreiras não-tarifárias (BNT), destacaram-se os temas agrícolas e de investimentos, e a necessidade de se criar um mecanismo para que o Congresso autorizasse a negociação de BNT, mecanismo esse que seria criado na lei de 1974, o fast track.

No relatório da Williams Commission, Baldwin (1971) argumenta a favor de se negociar BNT multilateralmente, o que a Comunidade Europeia e o European Free Trade Association (EFTA) já faziam nos seus âmbitos. As negociações dentro desses blocos tinham o objetivo de liberalizar o comércio e harmonizar políticas, e acabavam resultando em barreiras contra competidores externos como efeito colateral ou de maneira deliberada. Aconselhava-se acompanhar esse movimento e torná-lo multilateral, por meio de uma Rodada, para não prejudicar a liberalização tarifária já obtida. As principais BNT eram quotas, subsídios domésticos e à exportação, regras de compras governamentais, regulações técnicas e administrativas para produtos e procedimentos, e impostos aduaneiros. Apesar do ataque do setor privado norte-americano contra as BNT de outros países, Baldwin (1971) argumenta que os Estados Unidos estavam entre os países que contavam com mais barreiras comerciais. No caso de compras governamentais, tema que se tornaria um dos principais focos dos esforços de liberalização comercial do país até hoje, "the laws of most other countries appear on the surface to be much more liberal than the U.S. Buy American Act (1933)" (Baldwin, 1971, p. 649). Defendendo a necessidade de o Congresso autorizar o Executivo a negociar a liberalização de BNT, Baldwin 
(1971) propunha medidas que se assemelhariam ao fast track e a outras medidas institucionalizadas em 1974, como uma maior abertura ao setor privado:

It is important that the appropriate Congressional Committees hold hearings on non-tariff trade distortions that are sufficiently extensive for Congress to be informed as to the kind of changes Administration officials think might be possible. [...] Unless hearings of this sort are held, the efforts of negotiators may be frustrated because they are out of touch with Congressional intent on these matters, or foreign governments may even be reluctant to negotiate seriously with the U.S. for fear that these negotiations will ultimately come to naught. The experience with the ASP agreement will not soon be forgotten (Baldwin, 1971, p. 659).

Um dos textos produzidos pelo Departamento de Estado (1971) para a Comissão Williams ressalta a importância das relações econômicas internacionais como fundamental para boas relações políticas, destacando a cautela necessária com a Europa ocidental e o Japão. Seria interesse dos Estados Unidos buscar ajustes internacionais, por meio de maior coordenação de políticas econômicas domésticas, e conseguir compromisso de países superavitários importarem mais dos Estados Unidos. Mecanismos de ajuste internos, como a flexibilização do TAA, e o compromisso de outros países em aceitarem as exportações dos NICs e outros grandes novos exportadores, de modo a dissolver a necessidade de ajuste em um único país como resultado da competição internacional, também seriam do interesse norte-americano. Para o Departamento de Estado, a liberalização do comércio agrícola é, além de tarifas, uma questão de políticas domésticas. No que tocava ao crescente problema das BNT, o Departamento argumentava que a maioria delas era legal perante o GATT, como preferências em compras governamentais, subsídios à exportação, barreiras de segurança e de saúde e outras formas de incentivos governamentais que causam desvio de comércio: "Their elimination will require reaching into sensitive areas of domestic policy that have not hitherto been subject of international trade bargaining" (Department of State, 1971, p. 9).

No período, o entrelaçamento entre investimentos e comércio começa a ganhar maior visibilidade, pois o Departamento propunha uma nova Rodada de negociações multilaterais para regulamentar os investimentos internacionais negociações ao estilo das Trade Related Investment Measures (TRIMS). Reconhecia-se que "the growing return flows of earning, realty and licensing payments provide a major element of growing strength in our balance of payments" (Department of State, 1971, p. 11) e que em decorrência do crescente investimento direto dos Estados Unidos nos países industriais (cresceu o dobro das exportações) ocorreriam os seguintes problemas na década de 1970:

1. Extra-territoriality - Attempts to apply U.S. laws in such areas as export control, anti-trust and capital controls to foreign subsidiaries of U.S. parent 
Instituições e política comercial nos Estados Unidos: política internacional, demandas domésticas e...

companies sometimes conflict with the laws or policies of host nations. They resent the intrusion of U.S. law policy in firms under their jurisdiction (Department of State, 1971: 11).

2. Discrepant National Policies - Different national policies on taxation, antitrust regulation and controls on capital flows can distort international trade and investment (Department of State, 1971: 11).

3. Regional integration - Increasing Europeans economic and political integration introduces a new type of international investment problems. While favoring European integration, we need to assure that European investment policies do not become discriminatory or restrictive in the guise of measures to accelerate economic integration. We need increasingly to coordinate and consult with Europe on investment policies" (Department of State, 1971, p. 12).

Como resposta, o Departamento de Estado propunha esforços para harmonizar políticas nacionais por meio de negociações multilaterais e bilaterais, reinterpretando antigas regras ou criando novas leis, instituições e códigos. No caso do investimento direto nos países em desenvolvimento, afirmava-se que esses recursos eram parte cada vez mais importante como suplemento da assistência fornecida pelos Estados Unidos.

Perhaps foremost is the potential conflict between the aspirations of developing countries for political and economic independence and their needs for foreign capital, technology and management. As private investment grows as a major supplement to government development assistance, it appears inevitable that the incidence of conflict between investor and host country will increase. This likelihood suggests the need for careful drafting of our investment promotion policies, the improvement of mechanisms for forestalling or resolving conflicts, and the provision of appropriate protection for U.S. investors in developing nations (Department of State, 1971, p. 12).

Por fim, abordaremos o texto de Harold Malgrem, então membro sênior do Overseas Development Council, mais tarde apontado como deputy do STR. O texto de Malgrem contém muitas ideias que foram praticadas pelo STR e pela administração. Malgrem (1971) analisa a reciprocidade na negociação de BNT. Para ele, reciprocidade é de difícil mensuração, pois é muito difusa numa negociação. Por exemplo, cortar $10 \%$ de tarifas num segmento em alta expansão pode ser equivalente a cortar $50 \%$ de um segmento decadente. O problema é agravado no caso de $\mathrm{BNT}^{15}$.

(15) Porém, o autor enfatiza que a reciprocidade é importante como elemento político e que o conceito não deveria ser descartado, mas sim modificado. A reciprocidade não seria medida pela eliminação de BNT, mas sim pela adesão a "rules, guidelines, and codes of conduct, coupled with consultative procedures for complaints which can be measured in terms of deviations from those rules, guidelines and codes. The reciprocity must take the form of equal commitments by nations, rather than equivalent trade concessions measured in traditional terms" (Malgrem, 1971, p. 496). 
A perspectiva nessas negociações deve ser fundamentalmente qualitativa e não quantitativa. Áreas de BNT que precisariam de prioridade na elaboração de regras internacionais seriam a imposição nacional de quotas para importação, licenças de importação, subsídios à exportação e CVD, e regras para transformar BNT em tarifas (tarificação). Esses temas, como veremos, foram abordados na Rodada Tóquio.

$\mathrm{O}$ autor argumenta que a agricultura era pouco abordada pelo GATT e que muitos países tinham muitas práticas distorcivas. Para ele, a liberalização agrícola deve ser tratada de forma similar à de BNT, pois envolvem substancialmente políticas domésticas. Adicionalmente, a liberalização da agricultura deveria ser tratada em conjunto com os bens industriais, para oferecer melhores oportunidades de negociação. Malgrem (1971) atacava também a permissividade que o GATT dava aos acordos regionais, destacando a CEE, o EFTA e os acordos que esses blocos europeus têm com outros países, pois criavam barreiras aos Estados Unidos. Aborda também o tema do investimento, sugerindo modificação em políticas domésticas, ao afirmar que "The treatment of foreign direct investment, including company regulation, as well as portfolio investment (tax treatment, etc.) could also be covered in a trade negotiation, by an attempt to harmonize national policies and perhaps define the legitimate bounds of national sovereignty" (Malgrem, 1971, p. 510).

Ao final, propõe uma modificação profunda na orientação da política externa norte-americana, de modo a potencializar a política comercial, na direção de maior nacionalismo econômico em oposição ao internacionalismo político.

A more forceful U.S. position (...) would require a shift in our foreign policy priorities. We would have to put the economic objective of a fair multilateral trading system based on nondiscrimination ahead of our political unification objectives in Europe (or at least redefine the conditions under which we are politically willing to accept European practices) (Malgrem, 1971, p. 504).

O autor deixa clara sua oposição à instrumentalização da política de comércio pela política externa, o que é significativo para entender o novo posicionamento do STR e suas divergências com o Departamento de Estado, e demandava grande empenho presidencial nessa nova orientação ${ }^{16}$.

In the past, our foreign policy has usually placed economic objectives in the category of instruments to be used to gain overall political ends; whereas treating economic objectives as part of those ultimate ends is rarely thought of. For other nations, the economic issues are an essential part of their foreign policy decisions, because of their domestic politics. Can the U.S. foreign policy mechanism adjust in this new direction? If so, the negotiating system is likely

(16) "The Grand Design for U.S.-European relations in the late 1950's and early 1960's. It would have to be presented as part of an overall foreign policy posture relevant to the international political needs of the 1970's and 1980's". Com esse tipo de retórica, continua, "the necessary domestic political support might be easier to achieve than if the emphasis were placed solely on trade" (Malgrem, 1971, p. 511). 
to erode, and the international economic problems ahead more likely to increase than decrease (Malgrem, 1971, p. 514).

Além da preocupação com BNT, os três autores abordados especificamente destacaram a importância de tornarem eficientes os mecanismos ajuste doméstico por causa do aumento de importações, principalmente o TAA e a escape clause, assim como enfatizaram a necessidade de flexibilizar o câmbio por razões dos balanços de pagamentos e comercial.

Os textos do relatório de 1971 mostram a importância da interligação entre o setor privado, a academia e o governo nos Estados Unidos. Parte substancial das ações de política comercial norte-americanas corresponde às sugestões e apontamentos desse relatório, numa lógica de adaptação dos interesses domésticos às intenções de formatação da ordem econômica internacional. É importante destacar que o relatório apresentava parte significativa daquilo que seriam os "novos temas" da política comercial, intensificados na Rodada Uruguai, entre 1986 e 1994, e da Rodada Doha, iniciada em 2001.

\subsection{Transições e abalos no arranjo institucional doméstico}

A blindagem do Congresso ao protecionismo, proporcionada pelo arranjo institucional, foi enfraquecida por pelo menos quatro motivos. Primeiro porque os remédios administrativos forneciam alívio e defesa comerciais em níveis insatisfatórios para o setor privado. E como essas válvulas de escape dos congressistas não funcionavam bem, cresceu a pressão sobre os legisladores para tomarem posicionamento mais protecionista, na esfera legislativa, rompendo as bases do arranjo. Segundo porque a formulação e a condução da política comercial eram vistas como inadequadas. Mesmo com a criação do STR boa parte do setor privado e dos congressistas ainda viam-nas demasiadamente influenciadas pelo Departamento de Estado, que as instrumentalizava para fins de segurança em prejuízo de setores da economia nacional. Isso gerou questionamentos à delegação de autoridade comercial do Legislativo ao Executivo. Terceiro porque no plano das ideias começava um período de revisão dos princípios da política comercial norteamericana. Emergia no debate político doméstico uma noção de Fair Trade diferente da historicamente adotada no país, e que desafiava a ideia de livre-comércio. Por fim, houve a reforma do sistema político doméstico que fragmentou e dispersou o poder na Câmara e no Senado. O poder dos comitês, principalmente o de Ways and Means e o de Finanças, os dois mais importantes para o comércio e peças-chave no arranjo institucional, como veto-points, foi diminuído pela criação de subcomitês. Tais reformas, induzidas pelos jovens Democratas que não encontravam acesso ao poder e pelo escândalo de Watergate, tornaram o processo de política comercial mais poroso ao paroquialismo (Browne, 1995; Jacobson, 1990; Peters e Welsch, 1977; Weingast, 1989). Consequentemente, o Partido Democrata, historicamente liberal, 
perdeu coesão, pois muitos de seus políticos retiraram o apoio ao projeto de liberalização comercial como era à época. Tal mudança correspondia em muitos casos à posição de tradicionais eleitorados Democratas, como trabalhadores siderúrgicos, que passavam a se opor a políticas liberalizantes. Exemplo significativo, a AFL-CIO, principal representante dos trabalhadores organizados nos Estados Unidos, deixou de apoiar o livre-comércio, passando a defender cotas gerais para importações. Levaram a essa demanda o aumento da competição estrangeira em têxteis e vestuário, calçados, automóveis, aço e eletroeletrônicos, como TVs e rádios (Baldwin, 1984).

O Executivo procurava frear essas pressões, vetando leis de cunho protecionista. $\mathrm{O}$ receio de um efeito bola-de-neve de leis protecionistas, como no princípio da década de 1930, era latente. Uma válvula de escape para esta tensão foi o papel desempenhado pelo STR. Na administração Nixon, o STR assumiu um caráter nacionalista e duro nas negociações comerciais internacionais após William Eberle assumir a chefia da agência. Buscava-se romper o padrão negociador do Departamento de Estado, o qual - na opinião dos insatisfeitos estadunidenses - fazia demasiadas concessões, sem exigir reciprocidade. O STR teve também papel relevante nos processos de formulação e coordenação política, de modo a dissociar a política de comércio internacional da política externa, papel que cumpriu apenas parcialmente (Dryden, 1995).

Para lidar com as demandas internas numa fase de reconhecida transição, Nixon criou Council on International Economic Policy (CIEP), deixando o STR intocado e contribuindo para o deslocamento do internacionalismo na política comercial dos Estados Unidos. O objetivo do CIEP era que a coordenação da política econômica internacional em alto nível deixasse de ocorrer por um Departamento específico ou agência participante do processo de política econômica internacional. Segundo Cohen (1988), o CIEP foi considerado de grande valia por observadores da época, que acreditavam que finalmente a política econômica poderia ser tratada com mais racionalidade no nível federal. O Congresso também via o Conselho com bons olhos. Garantiu a ele vida temporária por meio de legislação e lhe conferiu um orçamento particular. Sob a direção de Peter Perterson, oriundo do setor privado, onde era chairman da Bell \& Howell, o CIEP teve papel decisivo em convencer Nixon de que a superioridade econômica norte-americana se exauria e sobre a importância de se colocar a política econômica em primeiro plano, numa perspectiva mais nacionalista. Para Peterson, outros países e pressões domésticas colocavam as políticas comercial e financeira em xeque, denotando a debilidade da administração. Era preciso agir com vigor em prol de interesses econômicos nacionais.

Para fortalecer o STR e firmar uma transição do internacionalismo para um viés mais nacionalista, a administração determinou que a agência também seria formuladora de estratégia, junto com CIEP, o Council of Economic Advisors (CEA), 
Departamentos, entre outras agências. Nas administrações anteriores, o STR tinha papel periférico na formulação da política comercial, concentrando-se na execução. Adicionalmente, o STR ficaria incumbido de lidar com disputas bilaterais, antes a cargo dos Departamentos de Estado, Comércio ou Agricultura. Esse fortalecimento produziu resultados, pois o STR passou a defender que, se era preciso reverter o déficit comercial de 1971, não era possível que os Estados Unidos atuassem com base na reciprocidade: era preciso obter concessões significativas, sem contrapartida. Como destacou Eberle, chefe do STR, ao comentar negociações com o objetivo mencionado acima com europeus e japoneses: "Don't forget for a minute [...] that we got every one of these concessions without making a single concession of our own. Not one damn thing" (Dryden, 1995, p. 161) ${ }^{17}$.

No entanto, pelo processo fragmentado de formulação política, o STR deveria compatibilizar sua posição com as dos Departamentos de Tesouro, Comércio, Agricultura, mais nacionalistas, por um lado; e Estado e CSN, mais internacionalistas, por outro. É importante destacar que o STR teve parte de suas funções distorcidas em relação às originalmente atribuídas. O STR continuava como uma ligação entre o Executivo, o Legislativo e com o setor privado, mas deixava de ser o coordenador de um comitê interagências de alto nível sobre política comercial, função que passava a ser do CIEP. O CIEP, por sua vez, não era um mero coordenador, pois também produzia posições. Dryden (1995) relata profundas tensões entre o grupo ligado à diplomacia e o STR, com sensível proeminência do primeiro. Essas eram provas de que o STR - e a política comercial - estava dissociando-se da diplomacia como nunca. Parecia cristalizar-se a ideia de que os Estados Unidos deveriam buscar compensações pela abertura comercial assimétrica do pós II Guerra. Buscava-se, ex post, reciprocidade.

É preciso destacar ainda que, ao apontarmos esses argumentos, nosso intuito é indicar ao leitor as visões políticas que passaram a dominar a estrutura administrativa de política comercial dos EUA, embora saibamos que essas visões sejam altamente criticáveis.

\subsection{O Trade Act de 1974 e o STR}

Pode-se dizer que o Trade Act de 1974 foi importante marco da transição entre o período de internacionalismo para o de política do Fair Trade (abordada adiante) (Stokes; Choate, 2001). O Trade Act de 1974 teve grande importância por renovar a delegação de autoridade comercial do Congresso para o presidente. Foi negociado com flexibilidade pelo Executivo, permitindo incursões profundas do

(17) Evidentemente a maior mostra da mudança na política econômica internacional dos EUA veio com a quebra de Bretton Woods e a imposição de $10 \%$ de sobretaxa sobre importações. Contudo, importa destacar que concessões liberalizantes foram obtidas do Japão em carros, informática, aviação leve, urânio, víveres, laranja e soja. Já da CEE, obteve-se concessões em subsídios em trigo, tarifas para cítricos e tabaco. 
Congresso e de grupos de interesse no que se refere aos procedimentos de defesa comercial (Cohen, 1988). Com isso, mais uma vez o protecionismo generalizado foi evitado em favor de uma política comercial liberalizante, porém, mais agressiva e com maiores possibilidades de alívio contra importações e práticas consideradas desleais.

O STR, após esta lei, tornou-se um dos coordenadores efetivos do processo de formulação de política comercial norte-americano. Anteriormente, com o CIEP, o STR participava da coordenação da política comercial, mas não tinha a primazia e frequentemente era preterido pelo Departamento de Estado ou pelo CSN. Depois que Robert Strauss assumiu o comando da agência, o STR paulatinamente passou a liderar a coordenação do processo comercial, que havia se tornado ainda mais fragmentado. O aumento da fragmentação ocorreu por causa da criação, por meio de lei, de comitês interagências e privados e do fortalecimento da participação de congressistas nas negociações comerciais internacionais. Muitas dessas mudanças confirmam tendências presentes nos debates sobre o Trade Expansion Act de 1962, especialmente a preocupação com a transparência e os vetores democráticos.

O Congresso, por sua vez, criou e modificou mecanismos institucionais para influenciar a política comercial praticada pelo Executivo. Por exemplo, criou a Seção 301, que deu poder ao presidente para lidar com práticas desleais, como legislação doméstica de outros países que discriminava os norte-americanos, e facilitou certificação de proteção sob escape clause, antidumping e countervailing duty (Mundo, 1999). O Trade Act de 1974 pode ser considerado mais um salto qualitativo no processo de formulação e execução da política de comércio exterior. Ao ampliar os vetores democráticos, fortaleceu os negociadores norte-americanos, legitimando suas demandas e recusas. Ao organizar a interlocução entre interesses privados e negociadores, melhorou a qualidade da informação à disposição dos últimos, a qual seria difícil de obter por meio de pesquisas e análises concentradas somente em órgãos da burocracia, ainda mais num momento de expansão e de crescente complexidade da agenda comercial internacional. A lei comercial de 1974 também pode ser considerada um ponto de referência institucional para a mudança dos objetivos da política comercial em comparação com o pós II Guerra. A política comercial ganhava legitimidade em si, voltada para ganhos econômicos nacionais, diminuindo sua instrumentalização para objetivos de segurança.

A lei comercial de 1974 também teve papel central na história da política comercial norte-americana ao criar o mecanismo fast-track. Sua criação foi a solução encontrada pelos congressistas para evitar a delegação excessiva de poder ao Executivo para negociar BNT, que poderiam ser em muitos casos políticas públicas. Com o fast-track, o Congresso estabelecia as extensões das concessões que o Executivo poderia realizar numa negociação internacional. Quando o Executivo estivesse prestes a concluir a negociação, ele apresentaria os resultados a membros 
do Congresso, que verificaria a adequação em relação àquilo que foi delegado. Com o aval do Congresso, o Executivo fecharia a negociação e passaria a redigir, juntamente com o Congresso, um projeto de lei para institucionalizar os resultados negociados. O projeto então é colocado em votação no Congresso para sua ratificação ou rejeição, sem a possibilidade de emendas (Mundo, 1999). Isso permitiria à administração realizar acordos comerciais com credibilidade, pois evitaria que o Congresso modificasse alguns elementos negociados, como aconteceu ao final da Rodada Kennedy, quando o Congresso se recusou a ratificar a eliminação American Selling Price, uma espécie de gatilho tarifário (Dryden, 1995).

De fato, com o fast-track o STR pôde negociar e garantir a ratificação da Rodada Tóquio, incluindo temas não tarifários (Winham, 1986). Na interpretação de Ikenberry (1988: 240), isso ocorreu porque o "fast-track procedure diminished the effectiveness of individual industry lobbing efforts and ad hoc congressional obstruction". Durante a negociação o STR dialogou com o setor privado e com congressistas. Aos representantes do setor privado reunidos nos comitês de aconselhamento foi dada a oportunidade de votar sim ou não sobre se o acordo atendia aos interesses nacionais. Já os congressistas puderam influenciar a formulação da política comercial, o que os agradou demasiadamente. O STR, enfim, parecia ser o representante definitivo entre o setor privado e o Congresso, por um lado, e o Executivo por outro (Dryden, 1995). Tudo indicava que a transição institucional e de postura da política comercial norte-americana havia sido completada. Como veremos, porém, a primeira administração Reagan foi período de reversão parcial desse quadro.

\section{A política do Fair Trade}

O período de incerteza e transição foi marcado por fenômenos que afetaram de maneira significativa a condição material norte-americana. A crise do dólar, a política externa rumo à détente e a ascensão econômica do Leste Asiático, são exemplos disso. O período do Fair Trade que se inicia em meados da década de 1980 é em boa parte resultado das mudanças acumuladas apontadas acima. É, contudo, catalisada pelo comportamento da primeira administração Reagan, como veremos abaixo. Dentre as diversas mudanças ocorridas, talvez a mais importante seja a nova interpretação da ideia de reciprocidade e o combate ao que se entendia por comércio desleal, ensaiados na década de 1970, e colocados em prática com maior intensidade nesse período.

No plano estratégico, uma visão diferenciada sobre a Guerra-Fria diminuiu a aceitação dos custos assimétricos das relações comerciais, sobretudo no segundo governo Reagan (Destler, 2005, p. 61). Vários motivos contribuíram para essa mudança, mas o principal parece ter sido a debilidade da competitividade norteamericana, e a percepção de que era injusto favorecer seus concorrentes. Enquanto 
na década de 1950 o Japão, por exemplo, deveria receber investimentos em grande quantidade para manutenção da aliança com os Estados Unidos, na década de 1980 este país era considerado seu principal rival no campo econômico. Isso demonstra o enfraquecimento do pensamento baseado na lógica da contenção, e o fortalecimento da condição econômica como variável importante para a segurança nacional norteamericana.

No campo econômico, a deterioração econômica agravou-se ainda mais neste período, sobretudo no primeiro governo Reagan, quando se reduziram os impostos e aumentaram-se os gastos, principalmente devido ao programa "guerra nas estrelas", o qual injetou recursos em setores de tecnologia de ponta. Esta combinação de políticas macroeconômicas contribuiu para os déficits orçamentário e comercial. O déficit na balança comercial dos Estados Unidos foi alvo constante de críticas domésticas neste período. Em meados da década de 1980, o déficit já havia atingido cerca US\$170 bilhões, alargando consideravelmente o déficit iniciado na década de 1970. Em 1989, por exemplo, as importações já haviam atingido US\$ 477,4 bilhões, o que representou uma elevação de 191,11\% das importações de 1980, enquanto as exportações atingiram US\$ 362,1 bilhões, elevação de 161,43\% das exportações de 1980, criando um déficit na balança comercial de US\$ 115,3 bilhões (Council of Economic Advisors, 2002). Por mais que os problemas de competitividade pouco se relacionassem às políticas adotadas em outros países e pudessem ser mais atribuídos ao valor do dólar e mesmo à precariedade do setor privado, tinha apelo eleitoral culpar outros países pela deslealdade e exigir uma postura mais agressiva e nacionalista da administração. As dificuldades econômicas estimularam a atuação de grupos de interesses com maus resultados a pressionarem congressistas por mudanças políticas. Demandava-se, ex post, reciprocidade dos parceiros comerciais.

\subsection{Reflexos institucionais: USTR e Seção 301}

No final da década de 1970, com a conclusão da Rodada Tóquio, entendiase que o STR havia se tornado um instrumento institucional adequado para formular e coordenar a política comercial dos Estados Unidos, com um caráter menos internacionalista. Desse modo, seria importante institucionalizar o fortalecimento do STR, o que ocorreu pelo Plano de Reorganização $\mathrm{n}^{\circ} 3$, implementado pela administração Carter em 1980, sob demanda do Congresso. De acordo com a Seção 1 do Plano (Committee on Ways and Means, 2003), o Office of Special Trade Representative (STR) passaria a ser o Office of the United States Trade Representative (USTR). A alínea (b), item 1 e 3, atribuía ao USTR a liderança, com o aconselhamento do Trade Policy Committee (TPC), no desenvolvimento e na coordenação da implementação da política comercial bilateral ou multilateral, 
incluindo commodities e investimento direto quando relacionado ao comércio internacional $^{18}$.

O chefe do USTR foi instituído como principal conselheiro do presidente para o comércio internacional e para outras políticas com impactos sobre o tema. É importante destacar que na alínea (b) item 2, o Plano reitera o papel de primazia do USTR: "The Trade Representative shall have lead responsibility for the conduct of international trade negotiations including commodity and direct investment negotiations in which the United States participates". Reconhecendo que o comércio não era parte da agenda cotidiana do presidente, caberia ao USTR maior atenção ao tema.

Além do Plano de Reorganização burocrática, a aprovação do Trade Agreements Act de 1979 promoveu mudanças importantes. Reformou o sistema de aconselhamento privado por meio do qual grupos de interesse mantinham diálogo e consultas institucionalizadas com a administração na negociação de acordos internacionais. Merecem destaque outras emendas à alínea (c) da Seção 135 da lei comercial, as quais adicionam "serviços" como um grupo econômico ao lado do industrial, agrícola e trabalhista. A Seção 1.103 abriu a possibilidade para que grupos de interesse voltados para serviços participassem do Comitê privado de aconselhamento à política comercial e para a criação de Comitês setoriais e técnicos voltados para serviços. Essa adição demonstra a importância crescente do setor de serviços para a economia norte-americana, algo incontestável no século XXI.

Essas modificações pareciam definir que o USTR seria a instituição central na política comercial, sendo o ápice de um movimento de transição. Contudo, Reagan não atribuiu alto valor à agência e preferiu trabalhar com outras instituições para a política comercial. O USTR, a despeito das prerrogativas da lei comercial, era apenas mais uma instituição dentro da confusa e fragmentada organização burocrática da primeira administração Reagan ${ }^{19}$ (Cohen, 1988; 2000). No início dos anos 1980, a política comercial de Reagan não refletia as expectativas construídas

(18) O USTR deveria também coordenar atividades de outras agências e Departamentos no que toca à expansão das exportações norte-americanas; pesquisas sobre política comercial, de questões de investimento direto e de commodities, incluindo o comércio Leste-Oeste; o combate às práticas desleais de comércio; e as questões comerciais relacionadas à energia.

(19) A estrutura organizacional de formulação e execução política econômica internacional dos Estados Unidos é tradicionalmente fragmentada, podendo apresentar grandes variações de uma administração para outra e mesmo no decorrer de uma administração (Cohen, 1988; 2000). Jackson, Davey e Sykes Jr. (2002) afirmam ser praticamente impossível mapear e conhecer toda a estrutura. Seguir a legislação não é suficiente, pois nem tudo o que estipula o Congresso em termos organizacionais é cumprido pela administração. Isto porquê os presidentes buscam criar sistemas de coordenação que julguem mais adequados à execução das suas tarefas. Em outras palavras, buscam organizar o Escritório Executivo da Presidência da maneira que entendem mais adequada (Jackson; Davey; Sykes Jr., 2002). 
ao longo da década de 1970, no sentido de ser mais dura e demandante no cenário internacional.

Com esse comportamento, as pressões sociais aumentaram sobre o Congresso, que passou a atuar em um contexto onde temas como o déficit norteamericano, a deterioração do trabalho e a transnacionalização da economia estavam em alta. Havia consenso no Congresso em relação à situação adversa na economia norte-americana e à urgência de criação de novos mecanismos institucionais para lidar com estes problemas. A diferença desse período, porém, é que no primeiro mandato de Reagan a administração tinha como bandeira uma política comercial liberal, sem agressividade e sem criação ou reforma dos remédios administrativos de modo a facilitar o alívio e a defesa comerciais. De forma mais acentuada, na primeira administração Reagan a defesa (principalmente retórica) do livre-comércio, a estabilidade das alianças internacionais e a simbiose dos dois ainda eram preocupações centrais que impediam a administração de assumir posição mais dura (Vigevani, 1995).

Assim, a presidência quebrou o padrão de comportamento existente desde a década de 1930, pois não atuou para esquivar o Congresso das pressões protecionistas por meio de iniciativas de política comercial ou modificações no arranjo institucional. Nesse caso, esperava-se que o Executivo incorporasse uma política agressiva de abertura de mercados e de nivelamento das condições de concorrência (level the playing field), mas esses movimentos eram percebidos pela primeira administração Reagan como políticas intervencionistas, nocivas ao impulso de busca de competitividade endógena que julgava ser necessário ao setor privado. Com isso, os filtros institucionais que protegiam o Congresso não tinham mais o mesmo efeito e sofreram deslegitimação baseada no déficit comercial que reconfigurou a arena política norte-americana (Destler, 1995).

Entre a posição mais voltada para o livre-comércio da administração e o fortalecimento de um viés legislativamente protecionista, uma espécie de meio termo foi obtida com a adoção da noção de Fair Trade (Mendonça, 2009). Além da redução de barreiras tarifárias e não-tarifárias, seria importante a adesão dos outros países a normas comuns. "Thus, as more and more pressure was placed upon elected officials, government policy turned increasingly to market practices abroad in an attempt to force others to adhere to American standards" (Goldstein, 1993, p. 176). Os padrões norte-americanos eram considerados os padrões justos e leais e, em decorrência disso, os EUA procuraram incorporá-los ao sistema multilateral de comércio. Diferente do período de maior internacionalismo, no entanto, crescia nos Estados Unidos a opinião de que esse país não deveria, e de certo modo nem teria capacidade, de exercer papel de mantenedor de última instância do sistema por meio de concessões assimétricas. Assim, a segunda metade da década de 1980 contou com políticas assertivas dos EUA que passariam a exigir, de maneira agressiva, que os 
parceiros comerciais se comportassem de acordo com o próprio entendimento norteamericano de comércio leal, assim como demandariam maior liberalização econômica e adesão a novos regimes de propriedade intelectual, serviços e investimentos. $\mathrm{O}$ papel de mantenedor do sistema agora passou a ser relacionado à identificação, negociação e eventual punição de cheaters e free-riders.

\subsection{Reagan e a consolidação do Fair Trade}

A política de Fair Trade começa a ganhar contornos institucionais no Trade and Tariff Act of 1984, aprovado em 5 de outubro. A lei incorporava temas novos, como proteção à propriedade intelectual, serviços e produtos de alta tecnologia. $\mathrm{O}$ Congresso fortaleceu os mecanismos de defesa comercial da Seção 201 (escape clause) e da Seção 301, mas recusou conceder proteção legislada a setores específicos. O título III do Trade and Tariff Act of 1984 estabelece um papel de destaque ao USTR. Ele "Directs the USTR to consult with Congress on trade policy priorities", reafirma a necessidade de a agência trabalhar a partir de informações de outros Departamentos e agências e atribui responsabilidades fundamentais nos casos de combate ao comércio desleal (CRS, Bill Summary and Status). O reforço ao papel do USTR pode ser interpretado como uma resposta do Congresso à relegação daquela agência e especialmente como reflexo de um período em que era corrente a percepção de que as decisões eram tomadas pelo Executivo, tornando as consultas com o Congresso e comitês de aconselhamento apenas formalidades (Stokes e Choate, 2001). O USTR, uma agência 'anômala' por estar situada no Escritório Executivo da Presidência, mas profundamente ligada ao Legislativo, era um dos meios utilizados pelo Congresso para modificar as relações entre os dois poderes.

Embora esta reforma tenha representado grande parte das demandas dos congressistas, o Congresso, particularmente o Senado, continuou profundamente descontente com a atuação de administração Reagan na área comercial. A deterioração da credibilidade do presidente naquela arena motivou modificações organizacionais e na política comercial em 1985 (Cohen, 2000; Destler, 1995). Decidiu-se, por exemplo, que a própria administração deveria iniciar processos sob a Seção 301 e não esperar a iniciativa de empresas (Dryden, 1995). Era a primeira vez que tal medida era proposta. O Departamento de Estado se opôs a essa medida, mas o USTR e o Departamento de Comércio se aliaram ao Departamento de Tesouro e conseguiram vencer o debate burocrático, argumentando de que o Congresso necessitava receber fortes sinais do Executivo para evitar o protecionismo. O USTR iniciou investigações contra Brasil, Coréia do Sul e Japão sob a Seção $301^{20}$. Além disso, Reagan autorizou restrições às certas importações provenientes do Japão e da

(20) Entre os processos movidos sob a Seção 301 estão: Japão - tabaco; produtos de couro; construção de aeroportos. Coréia do Sul - seguros. Brasil - informática. CEE - frutas enlatadas (Vigevani, 1995; Dryden, 1995; Destler, 2005). 
CEE. Essas medidas não aplacaram o Congresso. Para Schwab (1994), a insatisfação do Congresso superava linhas partidárias, denotando uma disputa entre os poderes Legislativo e Executivo. O Senado, por exemplo, aprovou unanimemente resolução em favor de retaliação contra práticas injustas do Japão, percebido como o ícone da deslealdade contra os EUA, no início de 1985. A partir daí, muitos outros projetos surgiram e, apesar de não serem bem-sucedidos, criaram a onda que desembocou na implementação do Omnibus Trade and Competitiveness Act de 1988, o qual institucionalizou uma noção de Fair Trade de forma ainda mais explícita com os dispositivos denominados Super 301 e Special 301 (Mendonça, 2009).

O Congresso necessitava mais do que nunca da blindagem do Executivo. A descentralização do sistema político interno, na década de 1970, tornava o Congresso mais frágil às pressões protecionistas. A atividade legislativa aumentou como resposta aos interesses privados, como podemos ver na tabela abaixo referente ao uso dos remédios administrativos. Mas aumentou também como maneira de impressionar a administração e trazer o Executivo de volta à liderança da política comercial, desviando o Congresso da mira dos grupos de interesse protecionistas. $\mathrm{O}$ recurso à escape clause diminuiu na década de 1980, apesar de leve aumento da taxa de aprovação. O pico ocorreu em 1984, período eleitoral e de formulação de legislação comercial, quando houve 7 solicitações. A proteção sob os mecanismos $\mathrm{AD}$ e CVD eram mais atraentes, além de toda conjuntura que favorecia o combate ao comércio desleal, porque as mudanças da lei de 1979 concentraram burocracia especializada para lidar com eles. O programa TAA recebeu mais solicitações, teve sua taxa de aprovação levemente aumentada ao longo da década e custou US\$ 1,6 bilhões, seis vezes mais que na década de 1970 .

É preciso notar que a emergência do tema comercial trazia vantagens políticas aos congressistas. Se durante a década de 1970 o comércio internacional foi percebido como tema cujas oportunidades políticas eram moderadas, embora crescentes, "Trade issues were becoming, to a greater extent, entrepreneurial issues as members increasingly saw the subject as worthy of investment of their discritionary time" (Destler, 1995, p. 81).

Tabela 1

Solicitação (s) e taxa de aceitação (t.a.) dos mecanismos de defesa e alívio comerciais

\begin{tabular}{l|c|c|c|c|c|c|c|c}
\hline \multirow{2}{*}{ Ano } & \multicolumn{2}{|c|}{ EC } & \multicolumn{2}{c|}{ TAA } & \multicolumn{2}{c|}{ AD } & \multicolumn{2}{c}{ CVD } \\
\cline { 2 - 9 } & $(s)$ & $($ t.a. $)$ & $(s)$ & $($ t.a. $)$ & $(s)$ & $($ t.a. $)$ & $(s)$ & $($ t.a. $)$ \\
\hline $1963-1974$ & 3 & $3 \%$ & 24 & $31 \%$ & 24 & $22 \%$ & 1 & $93 \%$ \\
\hline $1975-1978$ & 10 & $3 \%$ & 890 & $45 \%$ & 42 & $15 \%$ & 34 & $30 \%$ \\
\hline $1979-1991$ & 2 & $11 \%$ & 1.871 & $47 \%$ & 40 & $38 \%$ & 18 & $30 \%$ \\
\hline
\end{tabular}

Fonte: Goldstein (1993). 
Por iniciativa da liderança Democrata na Câmara, foi apresentado um projeto de lei que previa: a redução da arbitrariedade do presidente na aplicação da defesa comercial, especialmente para a escape clause; a retaliação contra países que não abrissem seu mercado aos EUA; e a transferência de poder do presidente para o USTR na utilização da Seção 301 - com ênfase em telecomunicações, - e o estabelecimento de quotas para países com elevados superávits com os EUA. O projeto foi aprovado por 295 a 115 na Câmara (Schwab, 1994; Dryden, 1995).

A administração se opunha veementemente ao projeto, acusando-o de protecionista. Já os senadores pareciam, em geral, favoráveis ao projeto. Porém, a reforma tributária era a prioridade da agenda e os senadores não conseguiram progredir no projeto da Câmara antes do final dos trabalhos legislativos de 1986. Com isso, o projeto da Câmara foi dispensado, evitando uma curva acentuada dos Estados Unidos rumo à unilateralidade do nacionalismo econômico. Contudo, o projeto foi novamente introduzido em 6 de janeiro de 1987, com o sugestivo nome de Trade and International Economic Policy Reform Act (Schwab, 1994). Desta vez, porém, o intento interessava à administração, que havia conseguido acordo internacional para a realização de uma nova Rodada do GATT e necessitava da extensão do procedimento fast-track. A presidência passava a ter ações mais assertivas na política de comércio internacional. Reagan chegou enfatizar, no tradicional discurso 'The State of the Union', a política de Fair Trade e a preocupação com a competitividade norte-americana, mas não foram ações suficientes para aplacar o Congresso (Schwab, 1994). Em 30 de abril o projeto da Câmara foi aprovado por 290 a 137, com adesão de 43 Republicanos e quase todos os Democratas.

O aumento de poder do USTR reafirmava a ideia de que o órgão instalado no Escritório Executivo da Presidência era criatura do Congresso e que estava sob influência do Legislativo. Esperava-se que, ao dar mais poder ao USTR, o que também havia sido feito pela lei de 1984, a agência poderia ser um contrapeso aos órgãos da administração mais voltados para o livre-comércio, assim como tornar a política comercial mais permeável ao Legislativo. A emenda chamada de Super 301 foi adicionada ao projeto, o qual foi aprovado pelo Senado, com amplo apoio bipartidário.

Para conciliar os dois projetos foi realizada uma conferência, onde os líderes congressistas conseguiram eliminar as medidas restritivas do projeto de lei devido à sua habilidade política e a um entendimento comum de que a política comercial adotar características mais agressivas. $\mathrm{O}$ desempenho comercial, em recuperação à época, facilitou o movimento, pois diluiu a força dos grupos de interesse contrários, ao mesmo tempo em que fortaleceu o lobby dos grupos exportadores. $\mathrm{O}$ procedimento fast-track foi renovado com alterações. Os maiores embates com o USTR, que representava a administração, ocorreram no que toca aos mecanismos de 
defesa comercial. A Seção 301 e a Super 301 eram temas delicados, pois os congressistas queriam linguagem mais agressiva para esses instrumentos representativos da nova postura que procuravam imprimir à política comercial -, assim como uma maior transferência de poderes do presidente para o USTR do que preferia a administração. Em 20 de abril, a Câmara aprovou o projeto por 312 a 107. Logo depois o Senado o aprovou por 63 a 36.

O presidente Reagan, no entanto, vetou o projeto. A transferência de poderes do presidente para o USTR não o agradou, mas dois trechos do projeto foram determinantes para o veto: um sobre o fechamento das fábricas; outro sobre a exploração de petróleo do Alaska. Houve votação para cassar o veto de Reagan, sem sucesso. O projeto voltou ao Congresso, e os trechos que provocaram o veto foram retirados. O projeto foi então aprovado por 376 a 45 na Câmara, por 85 a 11 no Senado e a lei foi sancionada em 23 de agosto de 1988 (Schwab, 1994; Destler, 1995; Mundo, 1999). Embora o projeto tenha sido vetado pelo presidente, os motivos do veto nada tiveram com o caráter pró-Fair Trade da lei; esta "was the culmination of four years of congressional activity. It was the first major trade bill initiated by the Congress since the days before Smoot-Hawley. And it was by far the longest trade bill passed by postwar Congress" (Destler, 1995, p. 96). Tinha mais de mil páginas, muito maior que as leis de 1962, 1974 e de 1979 que possuíam, respectivamente, 31, 98 e 173 páginas. Representava a crescente complexidade do comércio, a busca por revitalização e a necessidade de compromisso político doméstico.

Por meio da Super 301, em particular, o Congresso demandava ações unilaterais para lidar com obstáculos ao acesso a mercado para as exportações norteamericanas. O Japão era principal alvo, embora não o único. Com a Super 301, desejava-se adequar o sistema multilateral do GATT aos princípios do livre mercado no prazo mais curto possível. No longo prazo, a rivalidade entre as abordagens multilaterais e as bilaterais dependeria em grande parte dos resultados da Rodada Uruguai. Segundo Preeg (1995: 79-80), uma maior regulação das principais práticas comerciais "desleais" poderia frear a abordagem unilateral norte-americana, "but the unilateral genie, once out of the bottle, would be difficult to put back in". As ações da Seção 301 pareciam ser rápidas, eficientes e cada vez mais populares no Congresso dos EUA. Assim, se as ações unilaterais se repetissem constantemente provavelmente se transformariam em uma prática corriqueira.

Tendo em vista o embate entre o Congresso, mais protecionista, e o Executivo, mais livre-cambista, somado a isso um ambiente de internacionalização de empresas, a opção pelo Fair Trade se concretizou. Esta está relacionada ao receio de que políticas de competitividade e subsídios que outros governos possam dar às suas empresas resultem em vantagens para essas empresas em termos de atingir grandes escalas ou inovações no processo produtivo. É interessante notar que as grandes multinacionais norte-americanas preferiam a política do Fair Trade, pela 
qual o Estado norte-americano buscava eliminar o apoio e subsídios de outros Estados às suas empresas, ao invés de buscar a instauração do protecionismo nas próprias fronteiras dos EUA. Isso porque a reestruturação econômica mundial e os processos de transnacionalização da produção tornaram barreiras alfandegárias em um aumento de custo à produção, mesmo que no país sede da empresa.

A política de Fair Trade também possuía forte componente de interesse de Estado, o que é importante destacar para manter claro que a política comercial norteamericana não representa apenas interesses de grupos privados ou que é somente instrumento para objetivos gerais de política externa. Nos anos 1980, o Executivo, visando retomar a predominância econômica dos Estados Unidos, realizou esforços internacionais para proteger e incentivar indústrias e setores econômicos entendidos como fundamentais para revitalizar e fortalecer a posição econômica norteamericana. No caso de manufaturas, Milner e Yoffie (1989) e Krauss e Reich (1992) apontam que a simpatia a indústrias de alta tecnologia possuía forte ligação com o interesse de Estado. As atividades relacionadas a serviços e propriedade intelectual eram entendidas como atividades competitivas e com grande potencial econômico, fundamentais para manter os EUA numa posição de vanguarda. Deve-se salientar que o dinamismo desses setores demandava a abertura de mercados de acordo com a lógica neoliberal, a qual coincidia com os objetivos da administração Reagan.

\section{Conclusão}

Ao abordar a política comercial norte-americana historicamente, visualizamos como ocorreu parte importante de seu desenvolvimento institucional. Em conclusão, consideramos que quatro elementos merecem destaque para entender esses desenvolvimentos: o cenário político internacional, a situação econômica, a política doméstica e as ideias relativas ao comércio.

As variações no campo político-estratégico permitem correlações com os períodos internacionalista, de crise e de fair trade, mostrando impacto significativo nas mudanças das instituições de política comercial dos Estados Unidos. No auge da Guerra Fria, os esforços estavam concentrados nos temas de segurança militar, não havendo muito espaço para reivindicações estritamente comerciais. Com a diminuição do conflito, criaram-se condições para o surgimento do debate em torno de novos temas ligados ao comércio, como serviços, propriedade intelectual e investimentos, assim como para uma postura mais nacionalista.

No que toca à situação econômica, existe uma relação entre esta e as demandas para mudanças nas diretrizes de comércio. Com o bom andamento da economia, as políticas internacionalistas parecem ser mais estáveis. Já com o aprofundamento de crises econômicas, os interesses mais nacionalistas ganham 
força. A crescente dificuldade econômica que ocorrera na década de 1960, por exemplo, ajuda a entender a criação do STR.

A política doméstica norte-americana possui, aparentemente, um viesamento ao protecionismo, mas que foi arrefecido pelo desenvolvimento de arranjos institucionais que protegiam os congressistas de comportamentos paroquialistas. Tais arranjos, no entanto, não foram suficientes para superar o protecionismo agrícola. O enfraquecimento da blindagem durante a década de 1970 e a atuação fora do padrão da primeira administração Reagan desprotegeram o Congresso, o qual respondeu retirando poder da presidência e com instrumentos de fair trade.

Embora os elementos acima sejam relevantes, elas não provocam um efeito automático para o desenvolvimento das instituições de comércio. As mudanças no "mundo real" devem ser interpretadas pelos tomadores de decisões (políticos, burocratas, grupos de interesses etc.), e as reações políticas adaptativas a tais mudanças necessitam de uma certa aceitação da opinião pública norte-americana. Neste sentido, certas ideias influenciaram a atual política de comércio exterior dos Estados Unidos.

Apesar de destacarmos esses fatores como muito relevantes para a moldagem das instituições de comércio internacional dos EUA, entendemos que algumas características são de maior peso, mostrando um sentido em que estas instituições se modificaram e permaneceram imutáveis no decorrer do tempo.

Uma das modificações institucionais mais importantes do período analisado correspondeu à gradual autoafirmação da política comercial na agenda norteamericana. É o que representam, principalmente, a criação do USTR e os instrumentos da Seção 301. No primeiro período aqui abordado, que vai do pós II Guerra até meados da década de 1960, a divisão entre alta e baixa política se mostra de forma evidente, sendo claro que temas de segurança se caracterizavam por serem de alta política e os temas de comércio, de baixa política. Nesse sentido, a política comercial era um braço mais a serviço da política externa, sendo incapaz de dominar a agenda do Congresso. No período que chamamos de "Fair Trade", que se inicia a partir de meados da década de 1980, o comércio internacional passa a ter um lugar de destaque na agenda dos Estados Unidos. A política comercial ganha um novo status, ocupando uma alta posição hierárquica na agenda. A importância do USTR como agente negociador ficou fortalecida, ainda que com oscilações, assim como seu papel de interlocutor do Congresso junto ao Executivo.

Como elementos institucionais mais estáticos, notamos que o Executivo possui a tendência de manter um posicionamento mais pró-livre comércio do que o Congresso, que é mais aberto às demandas protecionistas. Porém, desde o pós II Guerra o impulso protecionista foi arrefecido por meio de arranjos institucionais 
elaborados, ou no mínimo aquiescidos, pelos legisladores. Deste modo, uma constante observada foi o padrão de criação e reforma dos mecanismos de defesa comercial como formas de absorção das demandas protecionistas de trabalhadores e empresários. Isso não quer dizer, entretanto, que os EUA tenham praticado uma política livre-cambista. $\mathrm{O}$ mercado agrícola foi mantido protegido em termos de acesso a mercado e de subsídios. O que buscamos destacar foi que alguns arranjos institucionais foram relevantes para permitir a política de liberalização tal como ela existiu.

Observamos também que uma resposta comum ao agravamento de tensões políticas referentes às diretrizes da política comercial foi a criação de novos espaços e canais de comunicação institucionais, com destaque para o sistema de aconselhamento privado do USTR. A abertura às demandas parece ter contribuído para direcionar a política comercial no sentido do fair trade.

Assim, no período analisado a política comercial dos Estados Unidos resulta fortemente das relações entre o Executivo e o Legislativo. Nos períodos observados, vimos a gravitação de uma política internacionalista de liberalização para uma mais nacionalista, voltada para o fair trade.

\section{Bibliografia}

ANDERSON, Robert B. The balance of payments problem. Foreign Affairs, Apr. 1960.

BALDWIN, Robert E. Non-tariff distortions of international trade. Washington, DC: United States International Economic Policy in an Interdependent World, GPO, Jul. 1971. v. I.

BALDWIN, Robert E. The structure and evolution of recent U.S. trade policy. Chicago/London: The University of Chicago Press, 1984.

BALDWIN, Robert E.; MAGEE, Christopher S. Congressional trade votes: from Nafta approval to fast-track defeat. Stockholm: Institute for International Economy, 2000. Disponível em: http://bookstore.petersoninstitute.org/book-store/92.html.

BARTON, John $\mathrm{H}$. et al. The evolution of the trade regime: politics, law, and economics of the GATT and the WTO. Princeton: Princeton University Press, 2006.

BLOCK, Fred L. Las origines del desorden économico internacional. México: Fondo de Cultura, 1980.

BROWNE, William P. Cultivating Congress: constituents, issues, and interest in agricultural policymaking. Kansas: University Press of Kansas, 1995.

CHANG, Ha-Joon. Chutando a escada: a estratégia do desenvolvimento em perspectiva histórica. São Paulo: Unesp, 2004. 
COHEN, Stephen D. The making of United States international economic policy. $3^{\text {rd }}$. ed. New York/West Port/Connecticut/London: Preager, 1988.

COHEN, Stephen D. The making of United States international economic policy. $5^{\text {th }}$. ed. New York/West Port/Connecticut/London: Preager, 2000.

COMMITTE ON WAYS AND MEANS. Overview and compilations of U.S. trade statutes. 2003 Edition. Washington: U.S. Government Printing Office, 2003.

COUNCIL OF ECONOMIC ADVISORS. Economic Report to the President (2002). Disponível em: http://www.gpoaccess.gov/eop/index.html. Acesso em: Feb. 1, 2006.

CRUZ, Sebastião Velasco e. Comércio internacional em um mundo partido: o regime do GATT e os países em desenvolvimento. Cadernos Cedec, n. 77, ago. 2005.

DEPARTMENT OF STATE. United States trade and investment policy in an interdependent world. Washington, DC: United States International Economic Policy in an Interdependent World, GPO: v. I, Jul. 1971.

DESTLER, I. M. American trade politics: system under stress. 2. ed. Washington: Institute for International Economics, 1992 / $3^{\mathrm{a}}$ ed.: Washington, DC: Institute for International Economics e New York: The Twentieth Century Fund, 1995.

DESTLER, I. M. American trade politics: system under stress. $3^{\mathrm{a}}$ ed. Washington: Institute for International Economics, 1992; $3^{\mathrm{a}}$ ed.: Washington, DC: Institute for International Economics e New York: The Twentieth Century Fund, 2005.

DRYDEN, Steve. Trade warriors: USTR and the American crusade for free trade. New York: Oxford University Press, 1995.

ECKES Jr., Alfred E. The trade policy process in historical perspective. Council on Foreign Affairs, 1999. Disponível em: http://www1.cfr.org/pub3521/alfred e eckes/the trade policy process in historical perspective.php . Acesso em: Nov. $22,2004$.

EICHENGREEN, Barry. A globalização do capital: uma história do sistema monetário internacional. São Paulo. Ed. 34, 2000.

FRIEDEN, Jeffry. Capitalismo global: história econômica e política do século XX. Rio de Janeiro: Jorge Zahar, 2008.

GILPIN, Robert. War and change in world politics. Cambridge: Cambridge University Press, 1981.

GILPIN, Robert. A economia política das relações internacionais. Brasília: UnB, 2002. (Coleção Relações Internacionais). 
GOLDSTEIN, J. Ideas, institutions, and American trade policy. International Organization, The State and American Foreign Economic Policy, v. 42, n. 1, p. 179217, Winter 1988.

GOLDSTEIN, J.; KEOHANE, Robert (Ed.). Ideas and foreign policy. Beliefs, institutions, and politics changes. Ithaca and London: Cornell University Press, 1993.

GOLDSTEIN, J.; GOWA Joanne. US national power and the post-war trading regime. World Trade Review, v. 1, n. 2, p. 153-170, 2002.

HAMILTON, A. A utilidade da União no tocante ao comércio e à Marinha. In: MADISON, J.; HAMILTON, A.; JAY, J. Os artigos federalistas (1787-1788). Rio de Janeiro: Nova Fronteira, 1993.

HELLEINER, Eric. States and the reemergence of global finance: from Bretton Woods to the 1990s. Ithaca: Cornell University Press, 1994.

HISCOX MJ. The magic bullet? The RTAA, Institutional Reform, and Trade Liberalization. International Organization, v. 53, n. 4, 1999.

HOBSBAWM, E. Era dos extremos. O breve século XX - 1914-1991. São Paulo: Companhia das Letras, 1995.

IKENBERRY, G. John. Conclusion: an institutional approach to American foreign trade policy. International Organization, v. 42, n. 2, 1988.

JACOBSON, Gary C. The electoral origins of divided government. Competition in U.S. House election, 1946-1988. Colorado: Westview Press, 1990.

KEOHANE, R. O.; NYE, J. S. Después de la hegemonía. Tradução de Mirta Rosenber. Buenos Aires: Grupo Editor Latinoamericano, 1988.

KENNEDY, Paul. Ascensão e queda das grandes potências. Tradução Waltersin Dutra. Rio de Janeiro: Editora Campus, 1989.

LIMA, Thiago. A resiliência da política de subsídios agrícolas nos EUA. Tese (Doutorado)-Unicamp, Campinas, 2014.

MILNER, Helen V.; YOFFIE, David B. Between free trade and protectionism: strategic trade policy and a theory of corporate trade demands. International Organization, The MIT Press, v. 43, n. 2, p. 239-272, 1989.

MALGREM, Harold B. Modes of negotiating in the 1970's". In: COMMISSION on International Trade and Investment Policy. United States international economic policy in an interdependent world. Washington, D.C.: U. S. G.P.O, Jul. 1971. (Commission's Report to the President. Compendium of papers, v. II). 
MENDONÇA, Filipe A. do P. Entre a teoria e a história: a política comercial dos Estados Unidos nos anos 1980. Dissertação (Mestrado)-Programa de PósGraduação em Relações Internacionais San Tiago Dantas (Unesp, Unicamp E PucSp), São Paulo, 2009.

MENDONCA, Filipe; LIMA, Thiago. A política comercial dos Estados Unidos no primeiro governo Obama: heranças, estratégias e desafios. Meridiano 47, Brasília, UnB, v. 14, n. 139, p. 38, 2013.

MUNDO, Philip A. National politics in a global economy: the domestic sources of U.S. trade policy. Washington, DC: Georgetown University Press, 1999.

NEWMAN, Katherine S. Troubled times: the cultural dimensions of economic decline. In: BERNSTEIN, Michael A.; ADLER, David E.(Org.). Understanding American economic decline. New York: Cambridge University Press, 1994.

OLIVEIRA, Ivan Tiago Machado. A regulação do comércio internacional agrícola: histórico e perspectivas. Brasília: Ipea: 2011. (Texto para Discussão, n. 1651).

O'SHEA, Timothy J. C. The domestic political setting of U.S. Trade Policy. In: WALTERS, Robert S. (Ed.). Talking trade: U. S. policy in international perspective. Boulder: Westview Press, 1993.

PLATTNER, Marc F. American democracy and the acquisitive. In: LICHT, Robert A. et al. (Ed.). South Africa's crisis of constitutional democracy: can the U. S. Constitution help? Washington, DC: AEI Press, 1994.

PETERS, John G.; WELCH, Susan. Legislative reform and public policy: an overview. Policy Studies Journal, Illinois, University of Illinois, v. 5, n. 44, 1977.

SCHATTSCHNEIDER, E. E. Politics, pressures and the tariff. Englewood Cliffs: Prentice-Hall, 1935.

SCHWAB, Susan. Trade-offs: negotiating the Omnibus Trade and Competitiveness Act. Harvard: Harvard Business School Press, 1994.

STOKES, Bruce; CHOATE, Pat. Democratizing U. S trade policy. New York: Council on Foreign Relations, 2001.

TRADE ACT OF 1974. Congressional Research Service Bill Summary \& Status for the Trade Act of 1974, Pub. L. 93-618, 88 Stat. 1978, enacted Jan. 3, 1975, codified at 19 U.S.C. ch. 12.

TRADE AND TARIFF ACT OF 1984. Congressional Research Service Bill Summary \& Status for the Trade and Tariff Act of 1984, Pub. L. 98-573, 98 Stat. 2948. 
TRADE EXPANSION ACT DE 1962. A bill to enhance the competitiveness of American industry, and for other purposes.H.R.4848 Sponsor: Rep Rostenkowski, Dan [IL-8] (introduced 6/16/1988).

VIGEVANI, Tullo. O contencioso Brasil X Estados Unidos da informática: uma análise sobre formulação da política exterior. São Paulo: Editora AlfaOmega/Edusp, 1995.

WEINGAST, Barry R. Floor behavior in the U. S. Congress: Committee power under the open rule. American Political Science Review, Washington, v. 83, n. 3, set. 1989

WINHAM, Gilbert R. International trade and the Tokyo Round negotiation. Princeton: Princeton University Press, 1986.

ZEILER, Thomas W. American trade and power in the 1960s. Columbia: Columbia University Press, 1991. 